\title{
Verdens tilstand efter COP21
}

\section{Af John Christensen}

Paris-aftalen, som man i sidste øjeblik enedes om under COP21 i Paris, efterlod mange detaljer til de videre forhandlinger. Fokus for COP22 i Marokko vil derfor dels være på den mere trivielle men nødvendige udmøntning af mange af elementerne, dels på implementeringen af klimaplanerne. Der vil fremover være behov for at koordinere regeringer og ikke-statslige aktører som byer, virksomheder og andre aktører for at nå målene.

Det lykkedes som bekendt det globale samfund, under ledelse af FN, at indgå to ambitiøse globale aftaler i 2015. Først blev der i september etableret enighed om 17 såkaldte bæredygtighedsmål (SDG'er) og dernæst blev der i december på COP21(Conference of the Parties) etableret den såkaldte Paris-aftale.

Efter mange års forhandlinger på begge områder er fokus flyttet til implementering. Der er dog stadig en del knaster, der skal forhandles, og et behov for, at ambitionerne på klimasiden skal strammes over tid. De større sammenhænge mellem SDG og klima vil ikke blive uddybet her, ud over at notere, at klima er et af SDG'er- ne, mål 13, som så opfyldes via Klimakonventionen. Ligeledes er der også konsensus om, at opnåelse af klimamålene er afgørende for opfyldelsen af en række af de andre SDG'er.

For en, der har deltaget i alle 21 COPmøder, var aftalen i Paris naturligvis et højdepunkt på mange måder, ligesom der var jubel i Kyoto i 1997, efter Protokollen faldt på plads. Erfaringen fra Kyoto er dog værd at analysere og kan bruges til at illustrere de store forskelle i processerne før og efter de to aftaler.

\section{Top-down eller bottom-up}

Meget simplificeret så var Kyotoprocessen fokuseret på at nå 'top-down' til nogle fælles men differentierede reduktionsmålsætninger for de industrialiserede lande, mens alle andre lande ikke skulle påtage sig $\mathrm{CO}_{2}$ reduktionsforpligtigelser. Dette lykkedes et stykke hen ad vejen, men kun med diverse politiske studehandler kom alle på listen. Fx var der åbenlyst masser af såkaldt varm luft i målsætningerne for en række lande i Østeuropa og Rusland.

I mange af landene var målsætningerne ikke fuldt politisk sanktionerede i de hjemlige parlamenter, og ratificeringsudvikling under FN's miljøprogram. 
Den internationale klimapolitik balancerer derfor mellem en begrundet optimisme baseret på Paris-aftalen og en mindre udtalt realisme, som tilsiger, at det ег nødvendigt med en hastigt accelereret indsats.

processen tog derfor omkring fem år, før protokollen kunne træde i kraft. En del af forsinkelsen skyldtes også, at ratificeringen teknisk var skruet sådan sammen, at Rusland til sidst var eneafgørende for ikrafttrædelsen, hvilket førte til mange andre politiske krav.

Som et kuriosum kan nævnes, at COP15 i København til dels var forberedt efter samme model, men forhandlingerne var basalt set ikke kommet så langt, at en aftale reelt var mulig, og derfor endte mødet med den politiske Copenhagen Accord, der bagefter skulle udmøntes i en aftaletekst.

Selv om mødet i København på mange måder internationalt og nationalt opfattes som en fiasko, er der to vigtige elementer, der bør tages med i bedømmelsen af COP15. For det første, at Accorden har sat ting på dagsordenen, som kom til at udgøre vigtige elementer i Paris-aftalen, fx den Grønne Klimafond og 1,5 grads-målsætningen. Dernæst, at top-down tilgangen viste sig ikke længere at være gangbar.

Forståelsen for klimaproblemets tekniske og politiske kompleksitet gør en topdown tilgang umulig, lige som det stod mere og mere klart, at en global løsning kræver globalt engagement.

Fokus efter København har derfor været på at udvikle en ny aftalestruktur, som kunne gøre det muligt at få alle lande med i en fælles aftale med det der i klimakonventionssprog hedder 'common but differentiated responsibilities'. Flere gange i processen var prognoserne usikre for, om det ville lykkes at få en aftale i hus, og selv efter det seneste COP-møde i
Lima i 2014 var der udbredt skepsis omkring mulighederne for at lande en fornuftig aftale i Paris.

De tidlige forhandlingssessioner i 2015 gav ikke grund til yderligere optimisme, men de franske diplomatiske indsatser, sammen med Perus, begyndte gradvist at tegne et billede af mulig succes. Dette blev yderligere understøttet af politiske signaler fra Kina, Indien og USA samt andre indflydelsesrige lande i forskellige bilaterale sammenhænge.

COP21 i Paris var derfor baseret på en 'bottom-up' proces med individuelle nationale planer - de såkaldte 'Intended Nationally Determined Contributions' (INDCs) - og et overordnet regelsæt for ratificering, rapportering og implementering samt støtte til ulandenes deltagelse.

De individuelle nationale planer er på denne måde et regeringssanktioneret dokument, som landet tager ansvar for. Dette gør ratificeringsprocessen nemmere, men tilsikrer ikke automatisk den nødvendige globale ambition for at nå de vedtagne målsætninger.

Vi er derfor efter Paris i en situation, hvor ratificeringen er sket hurtigere end de fleste havde forventet. Belært af erfaringerne fra Kyoto var landene blevet enige om, at Paris-aftalen trådte i kraft efter mindst 55 landes ratificering, dækkende mindst 55 pct. af den globale $\mathrm{CO}_{2}$-udledning.

Frem til Kinas og USA's ratificering af Paris-aftalen, dækkende henholdsvis 20 pct. og 18 pct. af verdens samlede $\mathrm{CO}_{2}$-udledning, i begyndelsen af september, var det gået relativt langsomt med at nå det procentvise mål. Men med de to 
stormagters udmelding og med verdens tredjestørste $\mathrm{CO}_{2}$-udleder Indiens ratificering den 3. oktober, var en global klimamilepæl inden for rækkevidde.

Sluttelig kom EU op i gear, hastebehandlede ratificeringen, og den 4 . oktober kunne også Europa-Parlamentet og et samlet EU ratificere Paris-aftalen. Det ser derfor ud som om Paris-aftalen når at træde i kraft, inden Marokko byder verden velkommen til COP22.

\section{Utilstrækkelige ambitioner}

Alle analyser af effekten af de nationale planer, inklusive UNEP's egen autoritative 'Emissions GAP Report' konkluderer dog, at effekten af de indmeldte landeplaner langt fra er tilstrækkelig og kun udgør mindre end halvdelen af de emissionsreduktioner, som er nødvendige for at holde sig under de to graders temperaturstigning i dette århundrede.

UNEP-rapporten vurderer desuden, at hvis ambitionerne ikke øges hurtigt, er verden på vej mod en temperaturstigning på mellem to og fire grader, hvilket vil få helt uoverskuelige konsekvenser.

Der er i Paris-aftalen indbygget en 'review og pledge'-struktur, hvilket betyder, at de nationale planer og deres implementering skal vurderes med faste intervaller med henblik på at justere ambitionerne gradvist så de kommer på linje med målsætningen.

Dette er naturligvis en nødvendig men $\mathrm{i}$ praksis formodentligt langt fra tilstrækkelig proces, med mindre der sker nogle uventede politiske eller tekniske gennembrud, der accelererer processen.

Den internationale klimapolitik balancerer derfor mellem en begrundet optimisme baseret på Paris-aftalen og en mindre udtalt realisme, som tilsiger, at det er nødvendigt med en hastigt accelereret indsats.

\section{Lima Paris Action Agenda}

Med de nationale planer og konventionsprocessens timing må en vigtig del af den krævede acceleration nødvendigvis komme fra ikke-statslige aktører som byer, virksomheder, finansinstitutioner, NGO'er osv. Baseret på denne erkendelse var Paris topmødet også opbygget, så den indeholdt to hovedkomponenter: den formelle forhandlingsdel, og en parallel Lima Paris Action Agenda(LPAA), som fokuserede på at demonstrere og fremme handling blandt ikke statslige aktører.

Der blev formelt set præsenteret 77 LPAA-initiativer, som dækker meget bredt fra skov, landbrug, byer, transport, energi, klimatilpasning osv. Derudover findes der mange andre initiativer af mere uformel karakter, og samlet set regner man med, at der er mere end 10.000 forskellige projekter og andre former for aktiviteter, der er initieret i LPAA processen.

Klimakonventionssekretariat, etableret allerede i 2014, er en dedikeret webportal til at synliggøre de mange initiativer - den såkaldte Non State Actor Zone for Climate Action (NAZCA), hvor de forskellige initiativer kan registrere deres aktiviteter.

I opfølgningen på Paris-mødet har der fra den franske regering været fokus på at skabe troværdighed omkring de mange initiativer og understøtte de mange aktørers engagement i den fortsatte konventionsproces. Dette er sket i samarbejde med Marokko, som er vært for COP22 og Peru som initiativtager til LPAA-processen og fokuserer på tre ting:

- at styrke og udbygge eksisterende initiativer og etablere nye hvor der er behov, fx på klimatilpasningsområdet

- at sikre øget integration mellem de nationale klimaplaner og de ikke statslige initiativer

- at opbygge dataindsamlingssystemer 
og rapportering med henblik på øget gennemsigtighed og troværdighed omkring resultaterne af de forskellige initiativer.

Som et første skridt har vi i UNEP-DTU Partnership faet ansvaret for den globale database, der skal følge de mange initiativer, og forsøger at dokumentere, hvad deres bidrag reelt er. Den nye Climate Initiatives Platform er et frivilligt registreringssystem, hvor LPAA-initiativerne anmodes om at rapportere på deres aktiviteter. Men på længere sigt må det forventes, at der gradvis kræves bedre og mere systematisk rapportering, hvis de forskellige initiativer fortsat vil anerkendes internationalt.

Hvordan denne gradvise formalisering og sammenknytning af de statslige og ikke-statslige aktører kommer til at fungere, er det for tidligt at spå om, og det vil være vigtigt at øget formalisering ikke resulterer i reduceret innovation og aktivitet.

Hvad er det så for nogle initiativer, der gemmer sig under den meget brede betegnelse 'ikke-statslige aktører'. En betegnelse, der i øvrigt også kan diskuteres, da der i flere initiativer også indgår stater.

I UNEP Gap-rapporten fra 2015 forsøgte vi at lave en kategorisering der omfattede:

- Byer og regioner

- Virksomheder

- Sektorer

Analysen viste hvor svært det er at få en konsistent struktur, da der fx på sektorniveau kan være overlap både med byer, regioner og virksomheder. Flere studier viser dog, at overlappet er minimalt, og for initiativerne selv er dette af mindre betydning. Overlappet har derimod afgørende betydning, når man forsøger at vurdere, hvor meget de forskellige initiativer bidrager ud over landeplanerne til den globale emissionsreduktion.

Flere internationale studier har forsøgt at analysere denne problemstilling for de forskellige større initiativer og prøvet at opgøre, hvor meget de bidrager til at løse den globale udfordring. Sådanne analyser er dog svære på grund af tre faktorer:

- De fleste initiativer er som beskrevet ovenfor baseret på frivillig rapportering, så der er for manges vedkommende ikke de nødvendige data og opgørelser over reduktionerne

- Samtidig findes der ikke et sammenligneligt rapporteringsformat mellem de forskellige initiativer

- Endelig er det ofte uklart i hvilket omfang de forskellige initiativer bidrager til den nationale indsats stipuleret i klimaplanerne. Det kan tilføjes, at mange klimaplaner stadig mangler detaljeret information omkring hvordan de forskellige opstillede mål skal opfyldes, og derfor også om resultaterne af de forskelige initiativer er medregnet.

Resultaterne af de forskellige internationale analyser varierer derfor ekstremt meget og afhænger mere af de forudsætninger der medtages end af facts.

Der er dog næppe tvivl om, at de ikke-statslige aktører spiller og kommer til at spille en central rolle i implementeringen af Paris-aftalens ambitioner, og sammenhængen med de nationale planer må forventes at blive klarere, efterhånden som planerne bliver udmøntet og implementeret.

\section{Byinitiativer}

Der er her ikke plads til at gå i detaljer med de forskellige initiativer, men som illustration af omfang, mangfoldighed og nogle af de beskrevne problemer med overlap og rapportering, skal der kort gøres rede for nogle af de vigtigste byinitiativer, og sluttes af med København som et eksempel på en aktør, der dels er enga- 
geret i flere af de beskrevne initiativer og dels er i stand til at holde ambitionsniveauet højt, på et tidspunkt hvor de nationale danske ambitioner desværre er under nedadgående pres.

C40 er et netværk der omfatter mere end 80 af verdens største byer med det formål af fremme handling på klimaområdet. Der arbejdes med erfaringsudveksling og samarbejder byerne i mellem, og der er samtidig gradvist opbygget et rapporteringssystem i samarbejde med andre initiativer for at dokumentere resultaterne. Byerne er forpligtede til årligt at rapportere på en lang række områder i et fælles format til et register i det såkaldte Carbon Disclosure Project. Det skal også oplyses, om data er verificeret af uafhængig ekspertise, og der er i det hele taget tiltagende organisering af rapportering mellem de forskellige byinitiativer.

'Covenant of Mayors' er et initiativ der oprindeligt udsprang af Europa-Kommissionens arbejde i 2008 med en ny klima- og energiaftale. Præmissen var, at byer i EU kunne tilslutte sig aftalen omkring EU's 2020 målsætninger frivilligt, men samtidig forpligte sig til ekstern vurdering af resultater og rapportering. I forbindelse med de nye 2030 mål for EU, der er en del af den fælles klimaplan til COP21, er antallet af deltagende byer nået op over $6000 \mathrm{og}$ flere kommer til.

Som en del af EU's input til COP-mødet i Paris er der politisk set arbejdet med at opbygge tilsvarende organisering af de større byer på det afrikanske kontinent og i Latinamerika. Da der ikke er fælles målsætninger for disse regioner er formatet nødvendigvis anderledes, men hensigten med at forpligtige byerne på handling er den samme.

Der findes en del andre byinitiativer, bl.a. er 'Compact of Mayors' et forsøg på at samle nogle af de forskellige initiativer under en fælles paraplystruktur, som bl.a. omfatter en fælles rapporteringsprotokol og et fælles registersystem kaldet 'Carbon Climate Registry'.

Pån nationalt plan har fx Brasilien etableret C27. Det er et netværk der inkluderer alle delstaternes hovedstæder med en ambition om at øge samarbejdet på klimaområdet. I Indien har regeringen lanceret et 100 smart cities-initiativ, som godt nok er nationalt drevet, men samtidig tilsigter at øge engagementet fra og samarbejdet mellem hundrede af de største byer i landet.

\section{København}

Vender man blikket hjemover, er det værd at notere sig, at Københavns kommune hoppede med på hypen omkring COP15 i København i 2009 og brugte COP15 som springbræt til formulering og vedtagelse af en tværgående klimaindsats. En samlet Borgerrepræsentation vedtog, 6 måneder før alverden mødtes til COP15 i København, en klimaplan med 50 konkrete initiativer og med en målsætning om, at man i København mellem 2005 og 2015 skulle reducere $\mathrm{CO}_{2}$-udslippet med 20 pct. En målsætning som byen indfriede i 2011. Samtidig fremlagdes også en vision om, at København i 2015 skulle være verdens første $\mathrm{CO}_{2}$-neutrale hovedstad

Klimaplanen satte for alvor København på klimaverdenskortet. Endvidere satte København for alvor byer og kommuner på dagsordenen, da København i samarbejde med C40 og 'Local Governments for Sustainability' ICLEI, inviterede til tre dages borgmestertopmøde, sideløbende med COP15.

Her deltog flere end 100 borgmestre fra alle kontinenter, og det er nok ikke 
helt forkert at sige, at byernes engagement i og muligheder for at påvirke klimadagsordenen rykkede tættere på de egentlige politiske forhandlinger. COP15 blev også den første COP, hvor kommunerne havde deres egen stand på selve COP-området, en anden markør på byernes og kommunernes udfordringer og lyst til at bidrage til den globale $\mathrm{CO}_{2}$-reduktion

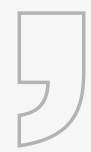

København er på mange måder et godt eksempel på en af de meget aktive byer, der er med til at øge ambitionsniveauet nationalt, samtidig med at man aktivt indgår i de globale by-initiativer.

København er i dag et aktivt medlem af C40, hvor overborgmesteren sidder i bestyrelsen. København er med som en såkaldt innovations by på baggrund af visionen om at blive verdens første $\mathrm{CO}_{2}$-neutrale hovedstad i 2025.

En vision, der blev politisk besluttet $\mathrm{i}$ 2012, i 'KBH2025-Klimaplanen'. Efter den politiske beslutning blev taget, har implementeringen taget fart. Vejen til $\mathrm{CO}_{2}$-neutralitet i København går via tre implementeringsfaser, hvor udgangen af 2016 markerer afslutningen på den første fase. Resultaterne har været positive, men skal København nå det ambitiøse mål om at blive $\mathrm{CO}_{2}$-neutral i 2025, er det klart at kommunen i den kommende periode skal igangsætte nye initiativer, der sammen med de allerede eksisterende skal sørge for reduktion af yderligere knap 300.000 tons $\mathrm{CO}_{2}$ for at København kommer i mål i 2025.

Om København lykkes med sin ambition er stadig for tidligt at sige, men samlet set indeholder aktiviteterne i den næste fase fra 2017-21 et stort potentiale for at komme et godt stykke mod målet, da der nu satses på områder, hvor der er potentielt er store $\mathrm{CO}_{2}$-gevinster at hente: Energiproduktion, mobilitet, energiforbrug og på kommunen som virksomhed.

I forhold til reduktionen på energiproduktionssiden afventer København diskussionerne om de nationale rammebetingelser for kystnære vindmøller og havvindmøller, da det er betydende for valg af løsninger. I forhold til at flytte sig $i$ en mere bæredygtig retning på mobilitetsområdet, fokuseres der på en række forskellige initiativer såsom $\mathrm{CO}_{2}$-neutral busdrift, der allerede afprøves forsøgsvis. Fremme af elbiler og forskellige delebilskoncepter vil også være i fokus via fremme af opladningsmuligheder, dedikeret parkering osv. Samtidig arbejdes der mere generelt med trængselsproblemer, da fremskrivninger viser, at trængslen i 2025 vil være fordoblet i og omkring København. Transportsektoren er et problembarn i de fleste byer verden over, og det er den sektor hvor emissionsudledningen stiger mest, så det må forventes at det er her København også vil møde de største udfordringer.

Københavns klimaplan, vision og de forskellige initiativer skal også tage højde for, at byen oplever en stor befolkningstilvækst, og i 2025 forventes bygningsarealet at være vokset med ca. 12 pct. Denne vækst sætter øget fokus på behovet for at bygge endnu mere energieffektivt og på for alvor at få sat energirenovering af de eksisterende bygninger på den politiske dagsorden. Med Københavns budget for 2017 har man taget hul på energirenoveringer i den almennyttige boligsektor, så implementeringen er også her i fuld gang med pilen sat mod at nå målet om $\mathrm{CO}_{2}$-neutralitet i 2025 . 
København er på mange måder et godt eksempel på en af de meget aktive byer, der er med til at øge ambitionsniveauet nationalt, samtidig med at man aktivt indgår i de globale by-initiativer. Om det lykkes for København at nå i mål, afhænger af den fortsatte politiske opbakning, de nationale rammebetingelser, og effekten af de forskellige partnerskaber med internationale, regionale og internationale aktører.

\section{COP22 og fremtiden}

Fokus for COP22 i Marokko fra 7. november og to uger frem vil dels være på den mere trivielle men nødvendige udmøntning af mange af elementerne i Paris-aftalen, som jo reelt blev færdigforhandlet den sidste nat i Paris, og derfor efterlod mange detaljer til de videre forhandlinger. Der vil dog parallelt være stærkt fokus på implementeringen af klimaplanerne og på dokumentation af, at de mange ikke-statslige initiativer faktisk leverer varen.

At den rekordhurtige ratificering ganske sandsynligt er faldet på plads inden COP22 åbner vil i sig selv betyde øget momentum. Det kan være den afgørende faktor, der sikrer den nødvendige acceleration af implementeringen af aftalen, der som tidligere beskrevet er bydende nødvendig for at gøre det muligt at opfylde de meget ambitiøse temperaturmål, der er opstillet i aftalen.

UNEP DTU hjalp før klimaforhandlingerne i Paris 35 udviklingslande med udarbejdelsen af deres nationale planer. Dette samarbejde fortsætter nu, med fokus på at gøre planerne operationelle og udmønte dem i konkrete aktiviteter. Samtidig er vi meget engagerede $i$ at fremme specifikt energieffektivisering på en lang række områder hvor teknologierne er til rådighed, mens det kniber med udbredelsen.

Belysningsområdet er et eksempel, hvor der med LED-pærerne findes en teknologi, der er fem til ti gange så effektiv som de traditionelle glødepærer, men hvor udbredelsen globalt kan accelereres væsentligt. Foreløbigt er der samarbejde med omkring 65 ulande for at fremme først forståelsen af mulighederne og siden lovgivning, der kan være med til at sikre en hurtig overgang til de nye pærer.

Et andet område, hvor Danmark står stærkt internationalt, er på fjernvarme og fjernkølingsområdet. Her har vi sammen med UNEP og en lang række danske og internationale virksomheder et voksende engagement med interesserede byer verden over om anvendelse af disse teknologier, et samarbejde der i øvrigt inkluderer København

Potentialet er kæmpestort, og ofte skal der kun en begrænset indsats til, for at øge forståelsen af mulighederne og fjerne evt. barrierer for øget anvendelse af disse mere effektive og $\mathrm{CO}_{2}$-besparende teknologier. I det hele taget viser alle studier, at energieffektivisering er det område, som hurtigst og billigst kan levere på den nødvendige øgede globale ambition, og der er stadig masser af muligheder selv i et relativt 'effektivt land' som Danmark.

De tekniske og økonomiske muligheder er derfor til stede for at accelerere de globale emissionsreduktioner hurtigt og effektivt. Det vil dog kræve, at både regeringer, ikke-statslige aktører såsom byer, virksomheder og andre aktører finder sammen i nye partnerskaber, og tager et kollektivt ansvar for den ultimative kollektive globale udfordring som klimaforandringerne udgør. 


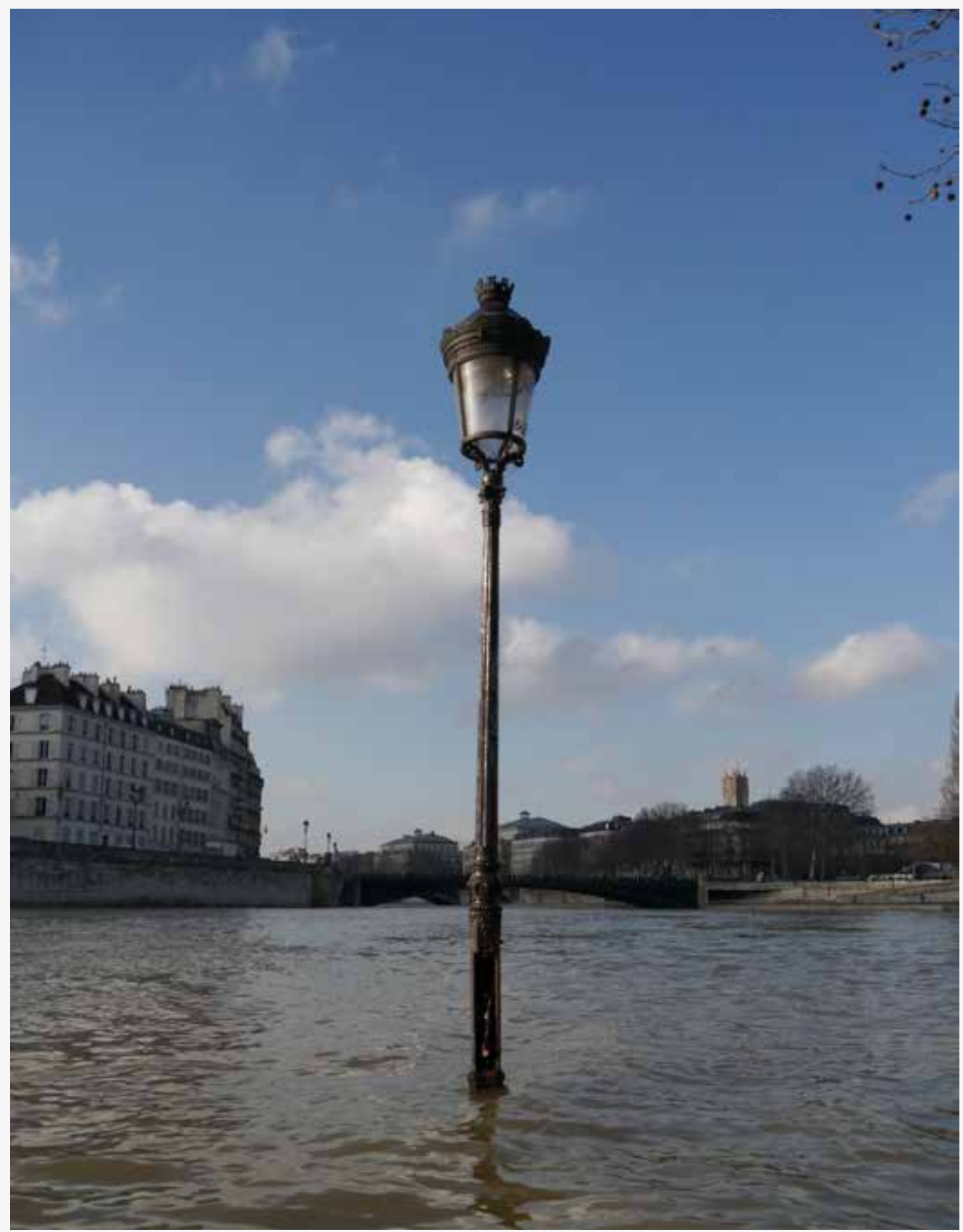

FOTO: Poulpry via Wikimedia Commons

Den vestlige del af Île Saint-Louis, Paris, efter at Seinen gik over sine bredder i februar 2013. 